\title{
Using of Wingeom Software in Geometry Learning to Improving the of Mathematical Representation Ability
}

\section{Mutia Fonna, and Mursalin}

Department of Mathematics Education, Universitas Malikussaleh, Aceh Utara, Indonesia

Corresponding author : mutia.fonna@unimal.ac.id; mursalin@unimal.ac.id

\section{ARTICLE HISTORY}

Received August 22, 2018

Revised September 27, 2018

Accepted October 3, 2018

\section{KEYWORDS}

Wingeom Software

Geometry Learning

Mathematical Representation Ability \begin{abstract}
The purpose of this study was to determine the use of Wingeom software in geometry learning in the Department of Mathematics Education. This type of research is quasi-experimental. This study examines the use of Wingeom software in geometry learning in the Department of Mathematics Education. The population in this study were all students of the Department of Mathematics Education under the Faculty Education and Teacher Training, Universitas Malikussaleh, and the samples were students of class A1 and class A2. The study was divided into two learning groups, namely the experimental group with the use of Wingeom Software and the control group with ordinary learning. This study begins with an instrument test which shows that (1) Validity indicates that the results are significant, (2) Very high reliability, (3) Good distinguishing power and (4) Moderate difficulty level. To test of homogeneity and normality that the data is homogeneous and normal. Based on the results of calculations using the $t$ test at the significance level $a=0.05$, obtained $t_{\text {count }}$ of 4.59 with a significance value of 0.003 while the table of 1.68. Because tcount $>t_{\text {table }}(3.127>1.68)$ and significance $<0.05(0.003<0.05)$. Then it can be concluded that the increase in the ability of mathematical representation of students who get learning with the use of Wingeom software is better than the ability of mathematical representation of students who get ordinary learning without Wingeom software.
\end{abstract}

This is an open access article under the CC-BY-SA license.

\section{INTRODUCTION}

The geometry is a subject matter of mathematics that requires mathematical abilities that are good enough to understand it. In Higher Education, especially in the Department of Mathematics Education at the Universitas Malikussaleh, one of the subjects studied is the Field Analytical Geometry course. This course is attended by students in even semester with a weight of 3 credits. The purpose of this lecture is that students are expected to be able to obtain and know the properties of points, lines, angles, and flat fields, and formulate and solve questions related to the arrangement of coordinates/vectors and vector fields, straight lines, circles, satellite dishes, ellipses, and hyperbole.

Based on the results of the observations that the author made during teaching this course and the results of discussions with several lecturers of the same subject, it turned out that many students had difficulties in understanding geometric concepts especially in solving problems of field points and vectors, straight lines, circles, and cone slices equations. The question arises in the mind of the author what causes difficulties for students to understand the analytical geometry concept of the field. From the initial analysis, the weakness of students in learning the lecture material is the inability of students to understand the concepts conveyed by lecturers during the teaching and learning process takes place. The unavailability of adequate media makes it difficult for students to understand abstract geometry concepts.
Achieving mathematical abilities students experience obstacles when they do not understand the relationship between concepts, ideas or material that will be represented. In solving problems related to mathematics, especially geometry, a mathematical ability that is good enough to understand is needed. This will later affect student achievement. Various mathematical abilities are expected to be achieved in learning mathematics ranging from elementary school to high school. The National Council of Teachers of Mathematics (2000) states that the five mathematical abilities students should have are (1) mathematical communication; (2) mathematical reasoning; (3) mathematical problem solving; (4) mathematical connections; (5) mathematical representation.

The importance of representation ability which is the basic ability to develop concepts and mathematical thinking, the unavailability of adequate media makes it difficult for students to understand abstract geometry concepts. If studied further regarding the relation between abstract geometric objects and the difficulties of students in learning geometry, then there will be suspicions that there are actually problems in learning geometry related to the formation of abstract concepts. Learning abstract concepts cannot be done only by transferring information, but it requires a process of concept formation through a series of activities experienced directly by students. The series of abstract concept formation activities is then called the abstraction process. Nurhasanah (Risnawati, 2012) argues 
that according to geometric characteristics, the abstraction process must be integrated with the learning process that takes place so that it must pay attention to several aspects, such as learning methods, learning models, teaching materials, availability and use of teaching aids or teacher skills in managing learning activities.

Various technologies and applications have been developed as an effort to support and facilitate teaching and learning activities in the world of education. One of them is in the field of Information and Communication Technology (ICT). Based on Law No. 14 of 2005, it was explained that in carrying out professional duties, teachers and lecturers were obliged to improve and develop academic qualifications and competencies on an ongoing basis in line with the development of science, technology, and art. One of the competencies related to ICT is utilizing technology to develop student understanding, and improve mathematical skills (NCTM, 2008). Technology in mathematics learning as meant in the form of calculators and computers. With computers, students can analyze more and varied examples and forms of representation (Dewi, 2016).

Based on the results of observations and problems faced by students in the field the authors are interested in solving the problems of analytic geometry in the fields faced by using the software. The software used in this study is Wingeom software. One of the advantages of this software is that it can be obtained and used for free. Wingeom software is a computer mathematics dynamic software for the topic of geometry. This program can be used to help geometry learning and geometry problem-solving. Based on the description above, the formulation of the problem that will be examined in this study is "how is the improvement in the ability of students' mathematical representation with the use of Wingeom software and learning without using the software?"

\section{METHODS}

The approach used in this study is a quantitative research approach, where the conclusion of the research data is described through statistical formulas. Quantitative research is conducted with the aim to see the effect of a treatment. This type of research is quasi-experimental research. The research design used by researchers was the pretest-posttest control group design proposed by Sugiyono (2011) with the following pattern:

Table 1. Design of Research

\begin{tabular}{llll}
\hline $\mathrm{E}$ & $\mathrm{O}_{1}$ & $\mathrm{X}$ & $\mathrm{O}_{2}$ \\
\hline $\mathrm{K}$ & $\mathrm{O}_{3}$ & & $\mathrm{O}_{4}$ \\
\hline
\end{tabular}

Information:

$\mathrm{E}$ is the experimental class

$\mathrm{K}$ is a control class

$\mathrm{O}_{1}$ and $\mathrm{O}_{2}$ are pree tests

$\mathrm{O}_{3}$ and $\mathrm{O}_{4}$ are post tests

$\mathrm{X}$ is a wingeom software learning treatment

This research was conducted on students of the Mathematics and Faculty of Education and Teacher Training, Universitas Malikussaleh an odd semester of the 2018/2019 academic year. The research period starts from April 1 to August 30, 2018. The population in this study are all even semester students from the Department of Mathematics Education, Faculty of Education Teacher Training, Universitas Malikussaleh. The sampling technique was using purposive sampling, namely students of class A1 and class A2. Data collection was done through initial tests and final tests in two classes. The data is analyzed using the appropriate statistical formula so that it will provide information that is in harmony with the things you want to examine. The collected data is processed using the t-test statistical formula as a testing tool for the hypothesis.

a. To test the normality of the sample, according to Sudjana (2005) a formula can be used:

$x^{2}=\sum_{i=1}^{k} \frac{\left(O_{i}-E_{i}\right)^{2}}{E_{i}}$

Information:

$\mathrm{Oi}=$ values that appear as observations

$\mathrm{Ei}=$ expected values $/$ theoretical values

b. To test the similarity of two variances according to Sudjana (2005), the formula is used:

$F=\frac{S_{1}^{2}}{S_{2}{ }^{2}}$

Information:

$\mathrm{S}_{1}{ }^{2}=$ the value of the experimental class variance

$\mathrm{S}_{2}{ }^{2}=$ the control class variance value

c. To test hypotheses according to Sudjana (2005) t-test statistics can be used:

$$
\mathrm{t}=\frac{\bar{x}_{1}-\bar{x}_{2}}{s \sqrt{\frac{1}{n_{1}}+\frac{1}{n_{2}}}}
$$

Information:

$$
\begin{aligned}
& \mathrm{t}=\text { value } \mathrm{t} \text { seek } \\
& \overline{\mathrm{x}}_{1}=\text { average test scores from the experimental class } \\
& \overline{\mathrm{x}}_{2}=\text { average test scores from the control class } \\
& \mathrm{n}_{1}=\text { the number of students in the experimental class } \\
& \mathrm{n}_{2}=\text { the number of control class students }
\end{aligned}
$$

The testing criteria are the right-hand test, which applies is to accept Ho if $t_{\text {count }}<t_{\text {table, }}$, reject $H_{o}$ if $t$ has other prices. Where $t$ $((1-\mathrm{a})(\mathrm{dk}))$ is obtained from the distribution list $\mathrm{t}$ for the real level $(\mathrm{a})=0.05$ and the degree of freedom $(\mathrm{dk})=\left(\mathrm{n}_{1}+\mathrm{n}_{2}-2\right)$.

The hypotheses formulated in this study are as follows:

Ho: $\mu 1=\mu 2$ the ability of mathematical representation using wingeom software is the same as the ability of mathematical representation with conventional learning in geometry courses for even semester students of the Department of Mathematics Education.

Ha: $\mu 1>\mu 2$ the ability of mathematical representation using wingeom software is better than the ability of mathematical representation with conventional learning in geometry courses for even semester students of the Department of Mathematics Education. 


\section{RESULTS AND DISCUSSION}

\subsection{Results of First Stage}

The details of the final test scores for each class are as follows: 1. The final test value of the experimental class student (A1)

$\begin{array}{lllllllllll}25 & 25 & 25 & 44 & 44 & 44 & 44 & 44 & 44 & 56 & 56 \\ 56 & 56 & 56 & 56 & 63 & 63 & 63 & 63 & 63 & 75 & 75 \\ 75 & 75 & 88 & 88 & & & & & & & \end{array}$

2. The final test score of the control class student (A2)

$\begin{array}{llllllllllll}19 & 25 & 25 & 25 & 25 & 31 & 31 & 31 & 31 & 31 & 31 & 44 \\ 44 & 44 & 44 & 44 & 44 & 44 & 50 & 50 & 50 & 50 & 56 & 56\end{array}$
56

Based on the post-test data from the two classes, the lowest score $\left(\mathrm{x}_{\min }\right)$, the highest score $\left(\mathrm{x}_{\max }\right)$, the average score $(\bar{x})$, and the standard deviation (s) for each class are as shown in Table 2 below:

Table 2. Results of Post-Test Data

\begin{tabular}{|c|c|c|c|c|c|}
\hline \multirow{2}{*}{ Group } & \multirow{2}{*}{ Score of Max } & \multicolumn{4}{|c|}{ Value of post-test } \\
\hline & & $x_{\min }$ & $x_{\max }$ & $\bar{x}$ & $\mathrm{~S}$ \\
\hline With Use of Wingeom Software & 100 & 25 & 88 & 56,23 & 17,06 \\
\hline Conventional & 100 & 19 & 56 & 37,53 & 12,77 \\
\hline
\end{tabular}

\section{Data Normality Test}

The purpose of the normality test is to find out whether the data is normally distributed or not.

Table 3. Results of Normality Test

\begin{tabular}{|c|c|c|c|c|c|c|c|c|}
\hline \multicolumn{9}{|c|}{ Normality Test } \\
\hline \multirow{2}{*}{ Groups } & \multirow{2}{*}{$\chi_{\text {count }}^{2}$} & \multirow{2}{*}{$\chi_{\text {table }}^{2}$} & \multicolumn{4}{|c|}{ Criteria } & \multirow{2}{*}{ Status } & \multirow{2}{*}{ Conclusion } \\
\hline & & & Accepted $I$ & $I_{0}$ & Refuse $H_{0}$ & & & \\
\hline With Use of Wingeom Software & 3,14 & 7,81 & $\chi_{\text {count }}^{2}$ & $<$ & $\chi_{\text {count }}^{2}$ & $>$ & $\chi_{\text {count }}^{2}<\chi_{\text {table }}^{2}$ & $\begin{array}{c}\text { Accept } H_{0} \\
\text { (Normal) }\end{array}$ \\
\hline Conventional & 6,25 & 7,81 & $\chi_{\text {table }}^{2}$ & & $\chi_{\text {table }}^{2}$ & & $\chi_{\text {count }}^{2}<\chi_{\text {table }}^{2}$ & $\begin{array}{c}\text { Accept } H_{0} \\
\text { (Normal) }\end{array}$ \\
\hline
\end{tabular}

Based on the results obtained in Table 3 above, it can be concluded that the data of the two samples are normally distributed.
The final test homogeneity test is used to determine whether the sample from the study has the same or homogeneous variance, so that this study can apply generally to the entire population.

\section{Data Homogeneity Test}

Table 4. Results of Homogeneity Test

\begin{tabular}{|c|c|c|c|c|c|c|c|}
\hline \multicolumn{8}{|c|}{ Homogeneity Test } \\
\hline \multirow[b]{2}{*}{ Group } & \multirow[b]{2}{*}{$s^{2}$} & \multirow[b]{2}{*}{$F_{\text {count }}$} & \multirow[b]{2}{*}{$F_{\text {table }}$} & \multicolumn{2}{|c|}{ Criteria } & \multirow[b]{2}{*}{ Information } & \multirow[b]{2}{*}{ Conclusin } \\
\hline & & & & Accept $H_{0}$ & Refuse $H_{0}$ & & \\
\hline $\begin{array}{l}\text { Wingeom } \\
\text { Software }\end{array}$ & 291,14 & \multirow[t]{2}{*}{1,78} & \multirow[t]{2}{*}{1,96} & \multirow[t]{2}{*}{$F_{\text {count }}<F_{\text {table }}$} & \multirow[t]{2}{*}{$F_{\text {count }} \geq F_{\text {table }}$} & \multirow[t]{2}{*}{$1,78<1,96$} & \multirow{2}{*}{$\begin{array}{l}\text { Accept } H_{0} \\
\text { (homogeneity) }\end{array}$} \\
\hline Convent & 163,21 & & & & & & \\
\hline
\end{tabular}

Based on the results obtained in Table 4 above, it can be concluded that the sample comes from a homogeneous variance of data groups. To test the hypothesis, the statistics used are the $\mathrm{t}$-test with a significant level of $\mathrm{a}=0.05$ and the degree of freedom for the distribution list $t$, namely $d k=(n 1+n 2-2)$. From the calculation of the post-test average score between LSQ learning classes and conventional classes, the results can be stated in Table 4.

Thus it can be concluded that the ability of mathematical representation of students using wingeom software is better than the ability of mathematical representation of students with conventional learning. In this study the results of learning and the ability of mathematical representation of students are very influential on lectures on geometry courses. According to Dewey (in Slameto, 2001) learning based on problems is the interaction between stimulus and response, is the relationship between two directions of learning and the environment. One of the important stages in learning using wingeom software is that students are taught to use software as a tool in understanding geometry, while helping to become independent in learning. Learning using wingeom software has a very large influence on improving the quality of student learning and aspects of mathematical representation abilities. Because through this software can help facilitate understanding, solve problems, complete graphics, images and their application.

\section{CONCLUSION}

Based on the results of the research and discussion, it was concluded that the ability of mathematical representation of students using wingeom software was better than the ability of mathematical representation of students with conventional learning. 


\section{REFERENCES}

Afandi, A. (2018). Difference of learning mathematics between open question model and conventional model. Malikussaleh Journal of Mathematics Learning (MJML), 1(1), 13-18.

Istarani. 2011. 58 Model Pembelajaran Inovatif. Medan: Media Persada

Putriani, D \& Rahayu, C. (2018). The Effect of Discovery Learning Model Using Sunflowers in Circles on Mathematics Learning Outcomes. International Journal of Trends in Mathematics Education Research, 1(1), 22-25. doi:10.33122/ijtmer.v1i1.26

Silberman. 2013. 101 Strategi untuk Mengajar secara Aktif. Jakarta: Indeks

Slameto, 2001. Belajar dan Faktor-faktor yang Mempengaruhinya. Jakarta: Bina.

Aksara

Sudjana. 2005. Metode Statistika. Bandung: Tarsito.

Sugiyono. 2011. Metode Penelitian Kuantitatif, Kualitatif dan R\&D. Bandung: Alfabeta

Dewi, S. (2016). Pengembangan Modul Matematika Diskrit berbasis Information and Communication Technology (ICT). Tesis SPs UNSYIAH. Banda Aceh: tidak diterbitkan.

Jones, B.F. dan Knuth, R.A. (1991). What does Research Say about Mathematics?

[Online].Tersedia:http://www.ncrl.org/sdrs/stwesys/2math.html .[11 April 2017]

Masitoh, L. F., \& Fitriyani, H. (2018). Improving students' mathematics self-efficacy through problem based learning.Malikussaleh Journal of Mathematics Learning (MJML), 1(1), 26-30.

Mursalin, M., Nuraini, N. L. S., Purnomo, H., Damayanti, N. W., Kristanti, D., Rohim, A., ... \& Fonna, M. (2018, September). The development of algebra teaching materials to foster students' creative thinking skills in higher education. In Journal of Physics: Conference Series (Vol. 1088, No. 1, p. 012101). IOP Publishing.

Mursalin, M. (2016). Pembelajaran Geometri Bidang Datar di Sekolah Dasar Berorientasi Teori Belajar Piaget. DIKMA (Jurnal Pendidikan Matematika), 4(2), 250-258.

NCTM (2000). Principles and Standards for School Mathematics. Reston, VA: NCTM

NCTM (2008).The Role of Technology in Teaching and Learning of Mathematics.

Plomp, T. 2010. Educational Desain Research: An Introduction to Educational Desain Research. Dalam Plomp, T, and Nienke N. (Eds). An Introductional to Educational Desain Research. Enschede: Nedherlands Institute for Curriculum Development.

Risnawati (2012). Pengaruh Pembelajaran dengan Pendekatan Induktif-deduktif berbantuan Program Cabri Geometry terhadap Peningkatan Kemampuan Representasi Matematis Siswa Sekolah Menengah Pertama. Tesis. SPs UPI. Bandung: tidak diterbitkan.

Sugiyono (2012). Metode Penelitian Pendidikan: Pendekatan Kuantitatif, Kualitatif, dan R\&D. Bandung: Alfabeta

Thahir, M., Roza, Y., \& Murni, A. (2018). Validity of learning website of kapita selekta mathematics course at UIN Suska Riau Students. Malikussaleh Journal of Mathematics Learning (MJML), 1(1), 19-25.

Trisnawati, T., Pratiwi, R., \& Waziana, W. (2018). The effect of realistic mathematics education on student's mathematical communication ability. Malikussaleh Journal of Mathematics Learning (MJML), 1(1), 31-35.

Usmadi \& Ergusni (2018). Design of ARCSI Learning Model with Scientific Approach for Teaching Mathematics in School. International Journal of Trends in Mathematics Education Research, 1(1), 13-18. doi:10.33122/ijtmer.v1i1.28.

Wigati Tri Utami. 2012. Identifikasi Kesulitan dalam menyelesaikan Persoalan Matematika yang berkaitan dengan Pecahan di kelas VIII SMP N 3 Ngaglik Sleman tahun Ajaran 2011/2012. Yogyakarta : Universitas Negeri Yogyakarta.

License information: This is an open-access article distributed under the terms of the Creative Commons Attribution License, which permits unrestricted use, distribution, and reproduction in any medium, provided the original work is properly cited. 